\title{
Bursa Uludağ Üniversitesi Sağlık Bilimleri Fakültesi Hemşirelik Öğrencilerinin Akılı Telefon Kullanım Durumu ve Bağımlılık Düzeylerinin Belirlenmesi
}

\author{
Aysel ÖZDEMIR, Halit ÇİTÇí, Sedat DAĞILGAN, Eda ÜNAL \\ 1 Bursa Uludağ Üniversitesi Sağlık Bilimleri Fakültesi, Halk Sağlığı Hemşireliği Anabilim Dalı, Bursa. \\ 2 Bursa Uludağ Üniversitesi Sağlık Bilimleri Enstitüsü, Hemşirelik Anabilim Dalı, Bursa.
}

\section{ÖZET}

Araştırma üniversite öğrencilerinde akıllı telefon kullanım nedenleri ve akıllı telefon bağımlılık düzeylerinin belirlenmesi amacıyla, KasımAralık 2018 tarihleri arasında, tanımlayıcı olarak planlanmıștı. Araștırmanın verilerinin toplanmasında bir üniversitenin hemșirelik bölümünde okuyan öğrencilerden örnekleme yapılmıştır $(\mathrm{n}=187)$. Araştırmaya katılan bireylerin \%67,4'ünün kız öğrencilerden oluştuğu görülmektedir. Öğrencilerin ölçekten aldıkları puan ortalaması $28,32 \pm 10,20$ 'dir. Öğrencilerin ilk kez akıllı telefona sahip olma yaşı/ son bir ay içinde cep telefonla ile en az konuştuğu süre ile akıllı telefon bağımlılık ölçek puanları arasında anlamlı ilişki saptandı $(\mathrm{p}<0,05)$. Öğrencilerin cep telefonunun günlük yaşantıdaki önemi ile akıllı telefon bağımlılık düzeyi ölçek puanı arasındaki ilişkiye bakıldığında: sağlık risklerini bilmesine rağmen cep telefonundan vazgeçemediği, prestij kaynağı olarak gördüğü, sorunlardan kaçmayı sağladığı, başkasına ihtiyaç hissetmesini önlediği, yalnızlık hissettirmediği, kendisine ait bir parçası olarak nitelendirdiği, sıkılmasını engellediği, yüz yüze konuşmalarda kendisini ifade etmede yaşadığı sıkıntıları azalttığını ifade eden durumlar ile akıllı telefon ölçek puanı arasında anlamlı ilişki olduğu saptanmıştır $(\mathrm{p}<0,05)$. Öğrencilerin cep telefonlarını değiştirme nedenlerinin( yeni telefonun çıkması, teknik özelliklerin yetersiz kalması, arkadaşlarından etkilenmek) akıllı telefon bağımlılık ölçeği puanlarını etkilediği belirlendi $(\mathrm{p}<0,05)$.

Anahtar Kelimeler: Akıllı telefon. Öğrenci. Bağımlılık.

Determination of Smart Phone Use Status and Dependence Levels of Nursing Students of

Bursa Uludağ University Faculty of Health Sciences

\begin{abstract}
The aim of this study was to determine the reason for the using smartphone and dependency level among the university students. This is a descriptive study conducted during November-December 2018. Data were collected from nursing students and the sample size was 187 students. Sixty-seven point four (67.4\%) of responders were women. The average score obtained from the scale $28,32 \pm 10,20$. Age of owning a smartphone/duration of the talking on the phone during last month correlates with smartphone usage addiction scale score $(\mathrm{p}<0.05)$. When relation with the importance of smartphones on students daily lives and smartphone usage addiction scale scores were evaluated; they can't give up from their phones even they know the risks to their health, they see it as a source of prestige, it helps them to run away from problems, avoid the feeling of need somebody else, does not feel alone, define as a part of themselves, avoid to be bored, it reduces the trouble the explain yourself when talking face to face and with all these situations we determined a significant relationship with the scale points of smartphone. $(\mathrm{p}<0,05)$. The relationship among the reasons of the students changing their phones (seeing new phones on sale, finding technical features of their old phones insufficient, the influence of friends) found to influence the scale scores obtained $(\mathrm{p}<0,05)$.
\end{abstract}

Key Words: Smartphone. Student. Dependency.

Geliş Tarihi: 01 Ağustos 2019

Kabul Tarihi: 14 Ekim 2019

\section{Dr. Aysel ÖZDEMIR}

Bursa Uludağ Üniversitesi Sağlık Bilimleri Fakültesi, Halk Sağlığı Hemşireliği Anabilim Dalı, Bursa.

Tel.: (0224) 2942472

E-posta: ayozdemir@uludag.edu.tr
Alexander GrahamBell Tarafindan 1876 yılında icat edilen telefon kısa sürede gündelik yaşamın bir parçası haline gelmiş, insanlar için iletișim kurabilme olanağı sağlamıştır ${ }^{1}$. İlk cep telefonu düşüncesi 1947 yılında Richard Frenkiel ve Joel Engel tarafindan ortaya atılmıştır. İlk mobil telefon da 1973 yılında Martin Cooper tarafindan icat edilmiştir ${ }^{2}$. Bu icat zaman geçtikçe teknolojik gelişmelerden etkilenerek kısa sürede evlerden çıkıp önce arabalara, ardından da ceplerde taşınabilir özelliklerde yapılmalarına olanak sağlamıştır. Günümüzde doğrudan internet üzerinden görüşmeye imkân sağlayan bu iletişim aracı mekân ve yer 


\section{A. Özdemir, ark.}

sınırlamasını tamamen ortadan kaldırarak ${ }^{1}$ dünyadaki fiziki mesafeleri yok etmiştir ${ }^{3}$.

Mobil cep telefonları, iletişimi yaşamın her alanına her saniye taşırken, bilgiye ulaşmayı da kolay ve hızlı gerçekleştirmektedir ${ }^{4}$. Başlangıçta sadece görüşme ya da kısa mesaj fonksiyonlarını kullandığımız cep telefonları, internet erişimi ve birçok özelliği sayesinde günümüzde vazgeçilmez bir nesne halini almıștır ${ }^{5}$.

Akıllı cep telefonlarının, diğer cep telefonlarından daha fazla bilgiyi işliyor olması internet erişimi, multimedya ve navigasyon gibi popüler bir cihaz olmasını sağlamıştır ${ }^{6}$. Akıllı cep telefonlarının kablosuz ağ özelliğinin olması internete her yerden ulaşımı kolaylaștırdığı için kullanıcılara kolaylık sağlamaktadır² Akıllı cep telefonları; iş ve eğlence aracı, bilgiye ulaŞım aracı, prestij aracı olarakta kullanılan çok fonksiyonlu bir cihazdır ${ }^{7}$. Cep telefonları aile, arkadaşlar ve bireylerarası iletişimi sağlayan (konuşma/ mesajlaşmak), internete bağlanarak oyun, müzik ve video erişimleri gibi birçok farklı alanda kullanılan önemli bir araçtır ${ }^{8}$.

Kemp'in verilerine göre; dünya nüfusunun 4.3 (\%57) milyar internet kullanıcısı ve saniyede 11 yeni kullanıcının eklendiği, 5.1 milyar kişi mobil telefon kullanıcısı ve 3.2 milyar kişinin de sosyal medya kullanıcıs1 olduğu ifade edilmektedir' ${ }^{9}$. Türkiye'de 1994 yılında başlayan cep telefonu piyasası özellikle genç yaşta olanların talebiyle sürekli gelişme göstermiştir ${ }^{10}$. Cep telefonu talep eden gençler arasında ise üniversite öğrencileri önemli bir bölümünü oluşturmaktadır ${ }^{11}$.

TÜİK 2016 verilerine göre Türkiye'de \%96,9'unda cep telefonu veya akıllı telefonu olduğu gerçeği günümüzde maddi durumu ne olursa olsun bireylerin neredeyse tamamının sahip olduğunu göstermektedir ve zorunlu ihtiyaç haline gelmiş bir grafik çizmekte$\operatorname{dir}^{12}$.

Pew Araştırma Merkezi (2018) gelişmiș ve gelişmekte olan 41 ülkeyi kapsayan araştırmasının sonuçlarına göre; internet kullanımı ve akıllı telefona sahip olma oranının zengin ekonomiye olan Avrupa ve Kuzey Amerika'da yaygın iken, Sahra altı Afrika ve Hindistan gibi gelişmekte olan ülkelerde düşük oranda olduğunu göstermektedir. İlk sırada \%88 oranla Güney Kore, bunu takip den \%77 oranla Avustralya, \%74 ile İsrail, \%72 ile Amerika ve \%71 ile İspanya takip etmektedir. Türkiye \%59 oranla 12.sırada yer almakta$\mathrm{d}_{10}{ }^{13}$.

Öğrenciler, eskiden sırt çantalarında taşıdıkları eşyalar1 şimdi teknolojinin değişmesiyle laptop, cep telefonu ve notepad gibi farklı teknolojilerle taşıyabilmektedirler. Genç kuşaklar günlük yaşantılarında teknolojiyi daha fazla kullanmakta, dolayısıyla da gençler gelişen yenilikleri toplumun her kesiminden daha önce takip etmektedirler ${ }^{14}$.

İnternetin kullanım alanları büyük bir hızla çoğalmaktadır. İTÜ 2018 yılı sonunda, dünya nun \%51,2’sinin veya 3,9 milyar insan, interneti kullandığını tahmin ediyor. Dünyada ki rin \%57,8'ininde internet olduğu ifade edilmektedir ${ }^{15}$. Artık kişiler interneti çok daha farklı amaçlarla ele almaktadırlar. Öyle ki; eskiden sadece bilgisayarlar üzerinden erişilen internet kullanımı artık her an taşıdığımız akıllı telefonlar üzerinden rahat bir şekilde bizlere erişim sağlamaktadır ${ }^{2}$.

Günümüzde çevreleriyle iletişimi kesmiş sanal gerçeklik yaşayan gençlik bulunmaktadır ${ }^{16}$. Bu gençler akıllı telefonlarıyla arama, mesaj yazma, e-posta gönderme ve alma, internette sörf yapma, sosyal ağlarda etkileşim, video ve fotoğraflara bakma ve paylaşma, video oyunu oynama gibi çok çeşitli uygulamaları yaygın bir şekilde yapmaktadır ${ }^{17}$. Teknolojinin sunduğu imkânlardan kontrolsüzce faydalanırken, pek kısa zamanda onların bağımlısı haline gelen bir nesil görülmektedir ${ }^{16}$. Kişiler sadece maddesel şeylere karş1 bağımlılık yaratmazlar. Oyun oynamak veya alışveriş yapmak gibi eylemlerde bir bağımlılık yaratabilir. Artık günümüz teknolojisi sayesinde akıllı telefonlarımızın bize sağladığı uygulamalarda bizlere bir bağımlılık yaratabilir².

Bağımlılık, bir madde ya da davranışı kullanmayı bırakamama veya kontrol edememe şeklinde tanımlanabilmektedir ${ }^{18}$. Bağımlılık, alkol ve uyuşturucu gibi belli bir maddeye biyolojik olarak bağlanmayla ve sinir sisteminin bir işlevi olarak ortaya çıkmaktadır. Özellikle teknolojinin gelişmesi ile teknolojik aletler toplumda çığır açan bir değișime yol açmış ve davranışsal bağımlılıkları da arttırmıştır ${ }^{19,20}$.

Akıllı telefon bağımlılığı için resmi tanı kriterleri mevcut değildir. Akıllı telefon bağımlılı̆̆ yönden internet bağımlılığına benzerlik göstermektedir. Ancak, kolay taşınabilirlik, gerçek zamanlı internet erişimi ve akıllı telefonların kolay ve doğrudan iletişim özellikleri gibi bazı farklılıklar da vardır ${ }^{6}$.

Bağımlılığın bireylerdeki boyutunu göstermek açısından iyi bir kanıt Tossell vd.'nin çalışmalarıdır. Yapılan çalışma sonuçlarına göre; katılımcıların çoğunluğu iPhone akıllı telefonları olmadan yaşamak yerine; dişlerini firçalamaktan, seks ve egzersiz yapmaktan, ayakkabılarını giymekten, çikolata yemekten ve duş almaktan vazgeçebileceklerini belirtmişlerdir ${ }^{21}$. Prometheus Danışmanlık Hizmetleri'nin yaptığı araştırmaya göre gençlerin yaşamlarında kaybetmekten en çok korktukları eşyanın \%91 ile cep telefonu olduğu istatistiğine ulaşmışlardır ${ }^{3,22}$. Çelik'in yaptığı çalışmada Türkiye'de cep telefonu kullanımının son zamanlarda modernliğin, çağdaşlığın göstergesi olarak görülmekte, her yeni telefon daha farklı iletişim olanakları sağlamaktadır ${ }^{23}$. Akıllı telefon bağımlılığı, kullanıcıların günlük yaşamlarını etkileyen akıllı telefonların aşırı kullanımı ile birlikte dikkat, tolerans ve kontrol kaybı, ruh hali değişikliği, geri çekilme semptomları ve özlem de dâhil olmak üzere çeşitli klinik özelliklere sahiptir ${ }^{24}$. 


\section{Hemşirelik Öğrencilerinin Akıllı Telefon Kullanımı}

Sağlık çalışanlarının aşırı akıllı telefon kullanımı nedeniyle hasta güvenliği tehlikeye girebilir. Bu nedenle, sağlık çalışanları arasında akıllı telefon bağımlılığı ele alınması gereken önemli bir konudur. Akıllı telefon kullanımının bağımlılığa yol açabileceğini ve hasta güvenliğini tehlikeye atabileceğini sağlık çalışanları olacak Sağlık Bilimleri Fakültesi öğrencileri için önemlidir. Bu çalışmamızda akıllı telefon kullanımının sağlık bilimleri fakültesi öğrencilerinde bağımlılık düzeyinin ölçülmesi amaçlanmıştır.

\section{Gereç ve Yöntem}

Hemşirelik Öğrencilerinin akıllı telefon kullanım durumu ve bağımlılık düzeylerinin belirlenmesi amacı ile kesitsel ve tanımlayıcı türde gerçekleştirildi. Araştırmanın verilerinin toplanmasında bir üniversitenin hemşirelik bölümünde okuyan öğrenciler evreni oluşturmuştur. Araştırmanın evreni (N) 580 kişi olup, bu çalışmada Raosoft örnekleme yöntemi kullanılarak \%5 hata ve \%95 güven aralığında kişi sayısı (n) 232 olarak hesaplanmıştır. Araştırmaya katılmak istemeyenlerin olması ve anketlerin eksik doldurulmas nedeniyle (n) 187 kişiden oluşmuştur.

\section{Veri Toplanması}

Araştırmada veri toplama aracı olarak araştırmacı tarafından literatür bilgisi doğrultusunda hazırlanan 20 sorudan oluşan anket formu ve Türkçe geçerlilik ve güvenirliği Noyan ve ark. (2015) tarafindan yapılan ‘Akıllı Telefon Bağımlılı̆̆ı Ölçeği Kısa Formu” ile toplanmıştır. $\mathrm{Bu}$ ölçekten alınabilecek maksimum puan 60, minimum puan 10'dur. Ankette toplam soru sayısı 30'dur. Testten elde edilen puan arttıkça bağımlılık için riskin arttığı şeklinde değerlendirilmektedir.

\section{Kişisel Bilgi Formu:}

Öğrenciler ait sosyo-demografik özellikler (yaş, cinsiyet, öğrenim durumu, meslek, medeni hal, gelir durumu vb.) ile akıllı telefon kullanım amac1, akıllı telefon değiştirme nedenlerine ilişkin bilgileri içeren toplamda 20 sorudan oluşmaktadır.

\section{Akıllı Telefon Bağımlılığı Ölçeği Kısa Formu:}

Türkçe geçerlilik ve güvenirliği Noyan ve ark. (2015) tarafından yapılan 'Akıllı Telefon Bağımlılığı Ölçeği Kısa Formu” ile toplanmıştır. Bu ölçekten alınabilecek maksimum puan 60, minimum puan 10'dur ${ }^{25}$.

Tanımlayıcı istatistikler nicel veriler için ortalama ve standart sapma, nitel veriler için frekans ve yüzde olarak belirtilmiştir. Verinin normal dağılım gösterip göstermediği Shapiro-Wilk testi ile incelenmiştir. Normal dağılım gösteren veri için iki grup karşılaştırmalarında t-testi 2'den fazla grup karşılaştırmalarında tek yönlü varyans analizi uygulanmıştır. Üç ve daha fazla grubun karşılaştırılmasında, gruplar arası farkın nereden kaynaklandığını belirlemek amacıyla çoklu karşılaştırma testlerinden Bonferroni testi kullanılmıştır. Değişkenler arasındaki ilişkiler için Pearson korelasyon katsayısı kullanılmıştır. Anlamlılık seviyesi $\alpha=0,05$ olarak belirlenmiştir. Verinin istatistiksel analizi SPSS23.0 (IBM Corp. Released 2015. IBM SPSS Statistics for Windows, Version 23.0. Armonk, NY: IBM Corp.) istatistik paket programında yapılmıştır.

\section{Etik Boyutu}

Araştırmanın yapılabilmesi için Sağlık Bilimleri Fakültesi/ Hemşirelik Bölümü Araştırma komisyonundan onay alınd. (Oturum Tarihi: 22.04.2017, Karar No 669)

\section{Bulgular}

Araştırmaya katılan öğrencilerin tanımlayıcı özellikleri Tablo I'de verilmiştir.

Tablo I. Öğrencilerin tanımlayıcı özellikleri ve Akıllı Telefon Bağımlılık Ölçek Dağılımı

\begin{tabular}{|c|c|c|}
\hline Özellikler & $\mathrm{n}$ & $\%$ \\
\hline 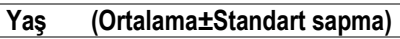 & \multicolumn{2}{|c|}{$20,42 \pm 1,6$} \\
\hline \multicolumn{3}{|l|}{ Sinif } \\
\hline 1 & 62 & 33,2 \\
\hline 2 & 67 & 35,8 \\
\hline 3 & 46 & 24,6 \\
\hline 4 & 12 & 6,4 \\
\hline \multicolumn{3}{|l|}{ Cinsiyet } \\
\hline $\mathrm{K} \mathbf{\prime z}$ & 126 & 67,4 \\
\hline Erkek & 61 & 32,6 \\
\hline \multicolumn{3}{|l|}{ Eğitim süresince yaşadığınız yer } \\
\hline Şehir & 148 & 79,1 \\
\hline İlçe & 25 & 13,4 \\
\hline Köy & 14 & 7,5 \\
\hline \multicolumn{3}{|l|}{ Eğitim süresince kaldığınız kişiler } \\
\hline Ailemle & 76 & 40,6 \\
\hline Okulun yatlı kısmında & 32 & 17,1 \\
\hline Arkadaşlarımla birlikte evde & 41 & 21,9 \\
\hline Akrabalarımla birlikte evde & 2 & 1,1 \\
\hline Diğer & 36 & 19,3 \\
\hline \multicolumn{3}{|l|}{ Anne eğitim düzeyi } \\
\hline Okuryazar değil & 16 & 8,6 \\
\hline Okuryazar & 21 & 11,2 \\
\hline İlkokul mezunu & 93 & 49,7 \\
\hline Ortaokul mezunu & 26 & 13,9 \\
\hline Lise mezunu & 26 & 13,9 \\
\hline Yüksekokul/üniversite mezunu & 5 & 2,7 \\
\hline \multicolumn{3}{|l|}{ Babanızın eğitim düzeyi } \\
\hline Okuryazar değil & 4 & 2,1 \\
\hline Okuryazar & 4 & 2,1 \\
\hline İlkokul mezunu & 65 & 34,8 \\
\hline Ortaokul mezunu & 36 & 19,3 \\
\hline Lise mezunu & 54 & 28,9 \\
\hline Yüksekokul/üniversite mezunu & 24 & 12,8 \\
\hline \multicolumn{3}{|l|}{ Aile tipiniz } \\
\hline Çekirdek aile & 153 & 81,8 \\
\hline Geniş aile & 27 & 14,4 \\
\hline Anne baba ayrı yaşıyor & 7 & 3,8 \\
\hline \multicolumn{3}{|l|}{ Gelir durumu* } \\
\hline Çok iyi & 5 & 2,7 \\
\hline lyi & 71 & 38 \\
\hline Orta & 106 & 56,7 \\
\hline Kötü & 5 & 2,7 \\
\hline
\end{tabular}




\section{A. Özdemir, ark.}

Araştırmaya katılan bireylerin \%67,4'ünün kız öğrencilerden oluştuğu görülmektedir. Bireylerin \%33,2'si 1. sinıf, $\% 35,8$ 'i 2 .sinif, $\% 24,6$ 's1 3.sinif ve \% 6,4'ü 4.sınıf öğrencilerden oluşmaktadır. Araştırmaya katılan bireylerin kendi ifadelerine göre ekonomik durumlar1; \%2,7'si kötü düzeyde ,\%56,7'si orta düzeyde, \%38'inin iyi ve \%2,7'sinin çok iyi olduğu bulunmuştur. Araştırmaya katılan bireylerin \%81,8'inin çekirdek tipi aile özelliğine sahiptir. Ebeveynlerinin eğitim düzeyine bakıldığında; üniversite düzeyinde eğitim alan anne $\% 2,7$ olup, babaların ise $\% 12,8$ ' $\mathrm{i}$ üniversite mezunudur.

Araştırmaya katılan öğrencilerin tanımlayıcı özellikleri ve Akıllı Telefon Bağımlılık Ölçek Puan Dağılımı Tablo II'de verilmiştir.

Tablo II. Öğrencilerin tanımlayıcı özellikleri ve Akıllı Telefon Bağımlılık Ölçek Puan Dağılımı

\begin{tabular}{|c|c|c|c|}
\hline Özellikler & 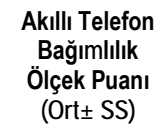 & $\begin{array}{c}\text { Test } \\
\text { değeri }\end{array}$ & $p$ \\
\hline \multicolumn{4}{|l|}{ Sinıf } \\
\hline 1 & $30,40 \pm 10,62$ & & \\
\hline 2 & $27,49 \pm 8,87$ & $F=2,671$ & $\begin{array}{c}0,049 \\
a\end{array}$ \\
\hline 3 & $28,43 \pm 10,98$ & & \\
\hline 4 & $21,83 \pm 9,74$ & & \\
\hline \multicolumn{4}{|l|}{ Cinsiyet } \\
\hline Kız & $28,57 \pm 10,34$ & $t=0,471$ & 0,638 \\
\hline Erkek & $27,81 \pm 9,97$ & & \\
\hline Akılı Telefon Bağımlılık Ölçek & $28,32 \pm 10,20$ & & \\
\hline \multicolumn{4}{|l|}{$\begin{array}{l}\text { Öğrencilerin Cep telefonu } \\
\text { kullanımına ilişkin özellikleri }\end{array}$} \\
\hline Cep telefonu kullanımı(yı) & $7,09 \pm 2,44$ & $r=-0,026$ & 0,724 \\
\hline Telefonla konuşma süresi(dakika/gün) & $100,19 \pm 233,11$ & $r=-0,007$ & 0,927 \\
\hline Bir konuşma süresi en az (dakika/gün) & $4,41 \pm 17,24$ & $r=0,159$ & 0,030 \\
\hline Bir konuşma süresi en fazla (dakika/gün) & $58,80 \pm 59,00$ & $r=0,131$ & 0,074 \\
\hline İlk cep telefonu alma yaşı & $13,57 \pm 2,39$ & $r=-0,091$ & 0,215 \\
\hline İlk akıllı telefonu alma yaşı & $16,70 \pm 2,16$ & $r=0,200$ & 0,006 \\
\hline Akıllı telefon kullanımı yıl & $3,90 \pm 1,96$ & $r=0,134$ & 0,067 \\
\hline
\end{tabular}

${ }^{\text {a }}$ Farklılık 1. ve 4. sınıf öğrencileri arasındadır.

Öğrencilerin Akıllı Telefon Bağımlıll̆̆g Ölçeğinden aldıkları puanların ortalaması 28,32 $\pm 10,20$ 'dir. Akıllı telefon bağımlılık ölçek puanları ile sinıflar arasında anlamlı farklılık olduğu saptanmıştır $(\mathrm{p}<0.05)$. Yapılan ileri analizlerde, Farklılık 1. ve 4. sınıf öğrencileri arasında olup, 2 ve 3 sinıf öğrencelerinin puanlarının birbirine benzer olduğu saptanmıştır. Akıllı telefon bağımlılık ölçek puanları ile cinsiyet arasında fark olmadığı saptanmıştır. İlk cep telefonu alma yaşı $13,57 \pm 2,39$ (Ort \pm Ss) ve ilk akıllı telefona sahip olma yaşı $16,70 \pm 2,16$ 'dır. Öğrenciler cep telefonunu 7,09 $\pm 2,44$ yıldır kullanmaktadır. Öğrencilerin ilk akıllı telefonu alma yaşı $16,70 \pm 2,16$ ve bir günde konuşma süresi en az ort.4,41 $\pm 17,24$ dak/gün'dür. Bir günde konuşma süresi ile Akıllı Telefon Bağımlılık Ölçek puanları arasında anlamlı( $\mathrm{r}=0-, 200, \mathrm{p}<0,05)$, ilk akıllı telefonu alma yaşı ile Akıllı Telefon Bağımlılık Ölçek puanları arasında anlamlı fakat çok zayıf bir ilişki olduğu saptandı $(r=0,159 ; p<0,05)$.

Öğrencilerin cep telefonun taşınması sırasında dikkat ettikleri ile cep telefonunun günlük yaşantıdaki anlamına göre Akıllı Telefon Bă̆ımlıllı̆ğ Ölçek puanlarının dağılımı Tablo III'de verilmiştir. Öğrencilerin cep telefonu taşırken dikkat ettikleri özelliklere bakıldığında; \%79,5'icep telefonunun taşındığı yerin önemli olduğunu ifade ettiği bulunmuştur. rin \%69,3'ü cep telefonunu çantasında, $\% 66,5$ 'i cep telefonunu kalbinden uzak bir yerde, \%27,8'i cep telefonunu arka cebinde, \%37,6's1 cep telefonunu başından uzakta taşımaya dikkat ettiği saptandı. Öğrencilerin \% 7,5'inin birden fazla telefonu vardır. Cep telefonu taşınılan yerin önemi, kalbimden ve başından uzak tutmaya dikkat etme, birden fazla cep telefonuna sahip olma ve uyurken cep telefonu kapatma durumu ile Akıllı Telefon Bağımlılı̆̆g Ölçeği puanları arasında anlamlı ilişki saptanmamıştır ( $\mathrm{p}>0,05)$.

Öğrencilere göre cep telefonunun günlük yaşantıdaki önemine bakıldığında; \%36,4'ü sağlık riskleri olmasına rağmen cep telefonundan vazgeçemediğini, \%37,6's1 yalnızlık hissetmesini önlediğini, \%87,0'si iletişim kaynağı olduğunu, \%28,4'ü prestij sağladığını, \%22,0'1 sorunlardan uzaklaştırdığı$\mathrm{n} 1, \quad \% 22,5^{\prime} \mathrm{i}$ vazgeçilmez bir parçası olduğunu, \%17,7'si bașkasına ihtiyaç duymayı engellediğini, \%89,7'si bilgiye ulaşmay1 kolaylaştırdığını, \%49,4'ü parayla alakalı konularda kolaylık sağladığını, \%65,0'sı sıkılmasını engellediğini,\%32,2'si yüz yüze konuşma sırasında yaşadığı sikıntıları azalttığını ve \%77,4'”ü acil durumlarda kolaylık sağlayan araç olarak ifade ettiği saptanmıştır. Öğrencilerin cep telefonunun günlük yaşantıdaki önemini ifade ettiği durumlara bakıldığında: sağlık risklerini bilmesine rağmen cep telefonundan vazgeçemeyen, prestij kaynağı olarak gören, sorunlardan uzaklaşmayı sağlayan, başkasına ihtiyaç hissetmeyi önleyen, yalnızlık hissettirmeyen, bir parçası olarak nitelendiren, sıkılmayı engelleyen, yüz yüze konuşmalarda kendisini ifade etmede sıkıntısı olanlar ile Akıllı Telefon Bă̆ımlıllı̆g Ölçek puanı arasında anlamlı farklılık saptanmıştır (Tablo-III).

Akıllı telefon kullanma amacı ile Akillı Telefon Ba$\breve{g}$ ımlılığl Ölçek puanı arasında anlamlı fark tespit edilmiştir. $(p<0,05)$. 


\section{Hemşirelik Öğrencilerinin Akıllı Telefon Kullanımı}

Tablo III: Cep telefonunun taşınması sırasında dikkat edilen özellikler ve cep telefonunun günlük yaşantıdaki anlamına göre Akıllı Telefon Bağımlılık Ölçek Puanının karşılaştırılması

\begin{tabular}{|c|c|c|c|c|c|c|}
\hline & & n & $\%$ & $\begin{array}{c}\text { Akıllı Telefon } \\
\text { Bağımlılık Ölçek } \\
\text { Puanı (Ort } \pm \text { SS) }\end{array}$ & Test değeri & p \\
\hline Cep telefonunun taşındığı yer önemli(n=186) & $\begin{array}{l}\text { Evet } \\
\text { Hayır }\end{array}$ & $\begin{array}{l}147 \\
38\end{array}$ & $\begin{array}{l}79,5 \\
20,5\end{array}$ & $\begin{array}{l}28,07 \pm 10,20 \\
29,24 \pm 10,59\end{array}$ & $t=-0,625$ & 0,533 \\
\hline Çantamda taşımaya dikkat ederim(n=150) & $\begin{array}{l}\text { Evet } \\
\text { Hayır }\end{array}$ & $\begin{array}{l}104 \\
46\end{array}$ & $\begin{array}{l}69,3 \\
40,7\end{array}$ & $\begin{array}{l}27,62 \pm 9,74 \\
28,85 \pm 10,24\end{array}$ & $t=-0,779$ & 0,437 \\
\hline Kalbimden uzak yerde taşırım(n=151) & $\begin{array}{l}\text { Evet } \\
\text { Hayır }\end{array}$ & $\begin{array}{l}92 \\
59\end{array}$ & $\begin{array}{l}66,5 \\
33,5\end{array}$ & $\begin{array}{l}27,53 \pm 10,05 \\
28,84 \pm 10,23\end{array}$ & $t=-0,773$ & 0,441 \\
\hline Arka cebimde taşımaya dikkat ederim(n=151) & $\begin{array}{l}\text { Evet } \\
\text { Hayır }\end{array}$ & $\begin{array}{l}42 \\
109\end{array}$ & $\begin{array}{l}27,8 \\
72,2\end{array}$ & $\begin{array}{l}29,51 \pm 10,25 \\
27,50 \pm 10,06\end{array}$ & $t=1,084$ & 0,280 \\
\hline Başımdan uzak yerde taşırım(n=151) & $\begin{array}{l}\text { Evet } \\
\text { Hayır }\end{array}$ & $\begin{array}{l}72 \\
79\end{array}$ & $\begin{array}{l}47,6 \\
52,4\end{array}$ & $\begin{array}{l}28,72 \pm 9,75 \\
27,46 \pm 10,46\end{array}$ & $t=0,762$ & 0,447 \\
\hline Cep telefonunu uyurken kapatırım(n=151) & $\begin{array}{l}\text { Evet } \\
\text { Hayır }\end{array}$ & $\begin{array}{l}30 \\
121\end{array}$ & $\begin{array}{l}16,0 \\
84,0\end{array}$ & $\begin{array}{c}29,56 \pm 11,16 \\
27,68 \pm 9,85\end{array}$ & $\mathrm{t}=0,916$ & 0,361 \\
\hline Birden fazla cep telefonu olma durumu (n=185)) & $\begin{array}{l}\text { Evet } \\
\text { Hayır }\end{array}$ & $\begin{array}{l}14 \\
171 \\
\end{array}$ & $\begin{array}{r}7,5 \\
92,5\end{array}$ & $\begin{array}{l}32,00 \pm 11,91 \\
28,01 \pm 10,09\end{array}$ & $t=1,404$ & 0,162 \\
\hline $\begin{array}{l}\text { Sağlık riskleri olmasına rağmen Vazgeçilemeyen } \\
\text { bir araç ( } n=187)\end{array}$ & \begin{tabular}{|l|} 
Evet \\
Hayır \\
Bazen \\
\end{tabular} & $\begin{array}{l}68 \\
100 \\
19 \\
\end{array}$ & $\begin{array}{l}36,4 \\
53,5 \\
10,1 \\
\end{array}$ & $\begin{array}{c}32,90 \pm 10,51^{a} \\
25,65 \pm 9,40^{b} \\
25,61 \pm 7,90^{b}\end{array}$ & $F=12,043$ & $<0,001$ \\
\hline Yalnızlık hissetmeyi önleyici(n=186) & \begin{tabular}{|l} 
Evet \\
Hayır \\
Bazen \\
\end{tabular} & $\begin{array}{l}70 \\
82 \\
34 \\
\end{array}$ & $\begin{array}{l}37,6 \\
44,0 \\
18,4 \\
\end{array}$ & $\begin{array}{l}33,39 \pm 9,35^{b} \\
23,20 \pm 9,71^{a} \\
30,03 \pm 7,33^{b}\end{array}$ & $\mathrm{~F}=23,834$ & $<0,001$ \\
\hline İletişim kaynağı(n=186) & \begin{tabular}{|l} 
Evet \\
Hayır \\
Bazen \\
\end{tabular} & $\begin{array}{l}162 \\
18 \\
6 \\
\end{array}$ & $\begin{array}{r}87,0 \\
9,6 \\
3,4 \\
\end{array}$ & $\begin{array}{c}28,63 \pm 10,32 \\
26,89 \pm 10,09 \\
24,00 \pm 9,38 \\
\end{array}$ & $\mathrm{~F}=0,777$ & 0,461 \\
\hline Prestij kaynağı(n=186) & \begin{tabular}{|l} 
Evet \\
Hayır \\
Bazen
\end{tabular} & $\begin{array}{l}53 \\
117 \\
16 \\
\end{array}$ & $\begin{array}{r}28,4 \\
62,9 \\
8,7 \\
\end{array}$ & $\begin{array}{c}31,43 \pm 10,37^{a} \\
26,40 \pm 10,02^{b} \\
31,81 \pm 8,56^{a b}\end{array}$ & $F=5,680$ & 0,004 \\
\hline Sorunlarımdan kaçma kaynağı(n=186) & $\begin{array}{l}\text { Evet } \\
\text { Hayır } \\
\text { Bazen }\end{array}$ & $\begin{array}{l}41 \\
111 \\
34\end{array}$ & $\begin{array}{l}22,0 \\
59,6 \\
18,4\end{array}$ & $\begin{array}{c}35,00 \pm 8,33^{a} \\
25,75 \pm 10,00^{b} \\
28,50 \pm 9,75^{b}\end{array}$ & $F=13,822$ & $<0,001$ \\
\hline Benim bir parçam (n=186) & \begin{tabular}{|l|} 
Evet \\
Hayır \\
Bazen \\
\end{tabular} & $\begin{array}{l}42 \\
120 \\
24 \\
\end{array}$ & $\begin{array}{l}22,5 \\
64,5 \\
13,0 \\
\end{array}$ & $\begin{array}{l}36,26 \pm 9,11^{a} \\
25,14 \pm 9,37^{b} \\
30,08 \pm 8,54^{b}\end{array}$ & $\mathrm{~F}=23,120$ & $<0,001$ \\
\hline Başkasına ihtiyaç hissetmeyi önleyici (n=186) & \begin{tabular}{|l|} 
Evet \\
Hayır \\
Bazen \\
\end{tabular} & $\begin{array}{l}33 \\
116 \\
37 \\
\end{array}$ & $\begin{array}{l}17,7 \\
62,3 \\
20,0 \\
\end{array}$ & $\begin{array}{l}36,03 \pm 9,25^{b} \\
25,14 \pm 9,46^{a} \\
31,57 \pm 9,07^{b} \\
\end{array}$ & $\mathrm{~F}=19,839$ & $<0,001$ \\
\hline Bilgiye kolay ulaşmamı sağlayan $(n=186)$ & \begin{tabular}{|l} 
Evet \\
Hayır
\end{tabular} & $\begin{array}{l}167 \\
19 \\
\end{array}$ & $\begin{array}{l}89,7 \\
10,3 \\
\end{array}$ & $\begin{array}{c}28,60 \pm 10,31 \\
25,79 \pm 9,69 \\
\end{array}$ & $\mathrm{t}=1,130$ & 0,260 \\
\hline Parasal işlemlerimi kolaylaştıran(n=186) & \begin{tabular}{|l|} 
Evet \\
Hayır \\
Bazen \\
\end{tabular} & $\begin{array}{l}92 \\
75 \\
19 \\
\end{array}$ & $\begin{array}{l}49,4 \\
40,3 \\
10,3\end{array}$ & $\begin{array}{c}27,88 \pm 9,97 \\
28,15 \pm 10,55 \\
31,00 \pm 10,68\end{array}$ & $F=0,741$ & 0,478 \\
\hline Sıkılmamı engelleyen $(n=186)$ & \begin{tabular}{|l} 
Evet \\
Hayır \\
Bazen \\
\end{tabular} & $\begin{array}{l}121 \\
36 \\
29 \\
\end{array}$ & $\begin{array}{l}65,0 \\
19,3 \\
16,7 \\
\end{array}$ & $\begin{array}{c}29,75 \pm 9,69^{a} \\
24,19 \pm 10,69^{b} \\
27,45 \pm 10,89^{a b}\end{array}$ & $F=4,331$ & 0,015 \\
\hline $\begin{array}{l}\text { Yüz yüze konuşmalarda kendimi ifade etmede } \\
\text { yaşadığım sıkıntıları azaltan(n=186) }\end{array}$ & \begin{tabular}{|l} 
Evet \\
Hayır \\
Bazen
\end{tabular} & $\begin{array}{l}60 \\
90 \\
36\end{array}$ & $\begin{array}{l}32,2 \\
48,3 \\
19,5\end{array}$ & $\begin{array}{c}31,42 \pm 10,75^{a} \\
25,59 \pm 9,81^{b} \\
30,00 \pm 8,88^{a b}\end{array}$ & $F=6,769$ & 0,001 \\
\hline Acil durumlara müdahale etmemi sağlayan( $n=186)$ & \begin{tabular}{|l} 
Evet \\
Hayır \\
Bazen \\
\end{tabular} & $\begin{array}{l}144 \\
27 \\
15 \\
\end{array}$ & $\begin{array}{r}77,4 \\
14,5 \\
8,1 \\
\end{array}$ & $\begin{array}{c}28,38 \pm 10,31 \\
27,48 \pm 9,40 \\
29,07 \pm 11,83 \\
\end{array}$ & $F=0,143$ & 0,866 \\
\hline $\begin{array}{l}\text { Akıllı telefonun en fazla hangi amaçla } \\
\text { kullanıyorsunuz( } n=186)\end{array}$ & $\begin{array}{l}\text { Kişisel } \\
\text { Sosyal }\end{array}$ & $\begin{array}{c}105 \\
79\end{array}$ & $\begin{array}{l}56,6 \\
43,4\end{array}$ & $\begin{array}{c}26,00 \pm 10,02 \\
31,35 \pm 9,89 \\
\end{array}$ & $t=3,607$ & $<0,001$ \\
\hline
\end{tabular}

a,b,ab Anlamlı bulunan sonuçların ikili karşılaştırmalarında benzer olan gruplara aynı sembol farklı olan gruplara farklı sembol verilmiştir.

Öğrencilerin cep telefonu değiştirme nedenleri ile Akıllı Telefon Bağımlılı̆̆g Ölçeği arasındaki ilişkinin dağılımı Tablo IV'de verilmiştir. Öğrencilerin \%96,8'i cep telefonunu değiştirmiştir. Öğrencilerin cep telefonu değiştirme nedenleri değerlendirildiğinde; \%80,1'i bozulduğu, \%32,0'si yeni telefonun çıması, \%,62,6's1 teknik özelliklerin yetersiz kalmas1, \%13,8‘i mesaj yazarken zorlandığı, \%9,4’ü marka takıntıs1, \%11,0'inin arkadaşlarından ği, \%30,9'unun ders notlarını okumakta zorland1- ğ1, \%27,1'i video izlemekte zorlandı̆̆ı, \%18,9'unun kitap/gazete okumakta zorlandığı, \%38,7'sinin sosyal medya kullanımında zorlandığı için değiştirdiği saptanmıştır. Öğrencilerin değiştirme nedenlerinden yeni telefonun çıkması, teknik özelliklerin yetersiz kalması, arkadaşlarından etkilenmek, sosyal medya kullanımında zorlanmak ile Akıllı Telefon Bağımlılı̆̆ arasında istatistik açısından anlamlı fark bulunmuştur $(\mathrm{p}<0,05)$. 
Tablo IV. Öğrencilerin cep telefonu değiştirme nedenlerine göre Akıllı Telefon Bağımlılık Ölçek Puanının karşılaştırılması

\begin{tabular}{|c|c|c|c|c|c|c|}
\hline Cep Telefonu Değiştirme Nedeni & & $\mathrm{n}$ & $\%$ & $\begin{array}{c}\text { Akıllı Telefon Bağımlılık } \\
\text { Ölçek Puanı (Ort } \pm \text { SS) }\end{array}$ & Test değeri & $\mathrm{p}$ \\
\hline \multirow{2}{*}{ Cep telefonumu değiştirdim(n=186) } & Evet & 181 & 96,8 & $28,40 \mathrm{t} \pm 10,21$ & \multirow{2}{*}{$t=0,848$} & \multirow{2}{*}{0,397} \\
\hline & Hayır & 5 & 3,2 & $24,00 \pm 13,39$ & & \\
\hline \multirow{2}{*}{ Bozulduğu için(n=181) } & Evet & 145 & 80,1 & $28,19 \pm 10,15$ & \multirow{2}{*}{$t=0,555$} & \multirow{2}{*}{0,580} \\
\hline & Hayır & 36 & 19,9 & $29,25 \pm 10,54$ & & \\
\hline \multirow{2}{*}{ Yeni telefonunun çıkması(n=181) } & Evet & 58 & 32,0 & $32,26 \pm 10,24$ & \multirow{2}{*}{$t=3,603$} & \multirow{2}{*}{0,001} \\
\hline & Hayır & 123 & 68,0 & $26,59 \pm 9,71$ & & \\
\hline \multirow{2}{*}{ Teknik özelliklerinin yetersiz kalması(n=181) } & Evet & 117 & 62,6 & $30,05 \pm 10,17$ & \multirow{2}{*}{$t=3,017$} & \multirow{2}{*}{0,003} \\
\hline & Hayır & 64 & 38,4 & $25,38 \pm 9,64$ & & \\
\hline \multirow{2}{*}{ Mesaj yazarken zorlandığım için( $n=181)$} & Evet & 25 & 13,8 & $30,80 \pm 11,63$ & \multirow{2}{*}{$t=0,850$} & \multirow{2}{*}{0,196} \\
\hline & \begin{tabular}{|l|} 
Hayır \\
\end{tabular} & 154 & 86,2 & $27,96 \pm 9,90$ & & \\
\hline \multirow{2}{*}{ Marka takıntısı(n=181) } & Evet & 17 & 9,4 & $31,06 \pm 11,34$ & \multirow{2}{*}{$t=0,128$} & \multirow{2}{*}{0,261} \\
\hline & Hayır & 164 & 99,6 & $28,13 \pm 10,08$ & & \\
\hline \multirow{2}{*}{ Arkadaşlarından etkilenmek( $n=181)$} & Evet & 20 & 11,0 & $33,65 \pm 10,08$ & \multirow{2}{*}{$t=2,471$} & \multirow{2}{*}{0,014} \\
\hline & Hayır & 156 & 89,0 & $27,75 \pm 10,07$ & & \\
\hline \multirow{2}{*}{ Oyun Oynamakta zorlanmak } & Evet & 25 & 13,8 & $31,96 \pm 11,43$ & \multirow{2}{*}{$t=1,890$} & \multirow{2}{*}{0,006} \\
\hline & Hayır & 156 & 86,2 & $27,83 \pm 9,92$ & & \\
\hline \multirow{2}{*}{ Ders notlarını okumakta zorlanmak(n=181) } & Evet & 56 & 30,9 & $29,45 \pm 10,36$ & \multirow{2}{*}{$t=0,920$} & \multirow{2}{*}{0,359} \\
\hline & Hayır & 125 & 69,1 & $27,94 \pm 10,15$ & & \\
\hline \multirow{2}{*}{ Müzik dinlemekte zorlanmak(n=181) } & Evet & 34 & 18,9 & $27,50 \pm 10,85$ & \multirow{2}{*}{$t=0,533$} & \multirow{2}{*}{0,568} \\
\hline & Hayır & 147 & 81,1 & $28,61 \pm 10,08$ & & \\
\hline \multirow{2}{*}{ Video izlemekte zorlanmak(n=181) } & Evet & 49 & 27,1 & $30,98 \pm 10,40$ & \multirow{2}{*}{$t=2,088$} & \\
\hline & Hayır & 132 & 72,9 & $27,45 \pm 10,01$ & & 0,038 \\
\hline & Evet & 33 & 18,2 & $29,48 \pm 10,88$ & $t-0.072$ & 0502 \\
\hline Kitap/gazete okumakta zorlanmak(n=181) & Hayır & 148 & 91,8 & $28,16 \pm 10,08$ & $t=0,672$ & 0,502 \\
\hline & Evet & 70 & 38,7 & $30,19 \pm 10,20$ & & \\
\hline Sosyal medya kullanımında zorlanmak(n=181) & Hayır & 109 & 61,3 & $27,13 \pm 10,04$ & $t=1,975$ & 0,049 \\
\hline
\end{tabular}

\section{Tartışma ve Sonuç}

İnsanlar gün içerisinde, internet, sosyal medya, telefon görüşmesi, oyun oynama ve bunun gibi sebeplerden dolayı birçok saatlerini akıllı telefon kullanarak geçirmektedir. Dünya üzerinde teknolojinin kullanımı erken yaşlarda başlamakta olup ${ }^{26}$, madde ve davranış bağımlılı̆ğ konusunda bu yaş grubuna dikkat edilmesi gerektiği unutulmamalıdır ${ }^{27}$. Akıllı cep telefonlarına yönelik yapılmış çalışmalar yaş arttıkça cep telefonu kullanım süresinin azaldığını göstermektedir ${ }^{28-30}$. Bu kanıt genç yaş grubundaki kişilerin risk altında olduğunu göstermektedir. Genç yaş nüfusun bu konuda bağımlılı̆̆ının azaltılması aile ve toplumun kısa ve uzun vadede yapması gereken çözüm yollarına odaklanmasını gerekli kılmaktadır.

Akıllı telefon kullanıcı sayısının ve bağımlılık seviyesinin her geçen gün arttığı bilinmektedir. Hastalık boyutuna gelen telefon ve sosyal medya kullanımı için dünya üzerinde çalışmalar yapılmakta ve tedavi önlemleri alınmaktadır.

Yapılmış çalışmalar ilk cep telefonuna sahip olma yaşının çok erken yaşlarda (8-13 yaş) olduğunu göstermektedir $^{26,31,62}$. Bizim çalışmamıza katılan bireylerin ilk cep telefonu alma yaş1 ort.13,57 $\pm 2,39$ ve ilk

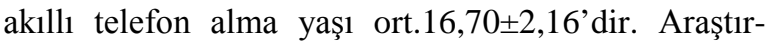
mamızdan elde edilen sonuç diğer araştırmaları destekler niteliktedir.
Cep telefonu ve internet bağımlılığı ile ilişkili yapılmış çalışmalarda; kadınların erkeklerden daha yüksek akıllı cep telefonu ve internet bağımlısı olduğunu göstermektedir $^{32-39}$. Bazı çalışmalar erkeklerin kadınlardan akıllı cep telefonu bağımlılığı puanlarının yüksek olduğunu ve internet bağımlısı olduğunu göstermektedir ${ }^{34,40-44}$.

Bizim çalışmamızda da kadınların erkeklerden daha yüksek akıllı cep telefonu bağımlılık puanı aldıkları saptanmıştır. Çalışmamızda, kadınların erkeklerden yüksek puanlarının olması, akıllı cep telefonu bağımlılığını etkilemediği ve cinsiyete özgü aralarında anlam${ }_{1}$ fark olmadığı bulunmuştur. Yapılan araştırmaların sonuçlarına bakıldığında; cinsiyete özgü puanlar değişiklik gösterse de cinsiyetler arasında farkın olmadığı$\mathrm{n}$ ı gösteren araştırma da vardır ${ }^{45}$. Bu çalışmalardan elde edilen sonuçlar; cinsiyet ve cep telefonu arasındaki ilişkinin seçilen örnekleme bağlı değişlik gösterdiği şeklinde yorumlanabilir. Bizim çalışmamızda akıllı cep telefonu bağımlılığı puanının kızlarda yüksek çıkması, aileden uzak olmak ve duygusal olmalarının bu duruma yol açabileceği şeklinde yorumlanmaktadır. Araştırmamıza katılan bireylerin cep telefonu kullanım yıl ort.7,09 $\pm 2,44$, akıllı telefon kullanım

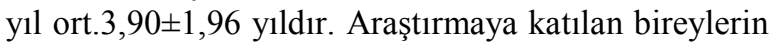
bir günde en az konuştuğu süre ort.4,41 17,24 saat / günde ve en uzun ort.58,80 $\pm 59,00$ ' saat / gün'dir. Bireyin günlük telefonla konuşma süre ort. $100,19 \pm 233,11$ ' saat /gün dür. Hadidi ve ark. (2019) yaptı̆̆ı çalışmada sağlık alanında öğrenim gören öğrencilerin cep telefonu kullanma durumu en yüksek 


\section{Hemşirelik Öğrencilerinin Akıllı Telefon Kullanımı}

ortalama ile diş hekimliği öğrencilerinde $(9,8 \pm 7,1)$ ve en düşük $(5.9 \pm 4.2)$ ile eczacilık olduğunu saptamışlardır. Aynı çalışmada hemşirelik bölümünde okuyanların ort. $5.8 \pm 5.6$ saat / gün olarak ifade edilmiştir ${ }^{48}$. Cep telefonu bağımlılığı ile ilgili yapılmış araştırmalarda, cep telefonu kullanım süresi bağımsız bir değişken olarak ele alınmış ve bağımlılık riskinin süreyle arttığı şeklinde sonuçlara ulaşılmıştır ${ }^{27.28 .47,48}$.

Türkiye telefon konuşma süreleri bakımından, Avrupa ülkeleri arasında ilk sıralarda yer almaktadır. Mobil abone başına düșen aylık ortalama konuşma süresi 400 dakikadan fazladır ${ }^{30}$.Araştırmamıza katılan öğrencilerin aylık telefonla konuşma süresi, Türkiye ortalamasına göre düşük bulunmuştur. İnsani ve Sosyal Araştırmalar Merkezi' (2015) verilerine göre telefon kullanımı süresi ile bulunduğumuz ortam arasında pozitif yönlü ilişki olduğunu göstermektedir. Bireylerin aile ortamının, telefon ve sosyal medya bağımlı11ğını etkilediği saptanmıştır. Sağlıklı aile ortamlarının ve aile içerisinde demokratik yaklaşımın, telefon ve sosyal medya bağımlılı̆̆ını düşürdüğü ifade edilmektedir ${ }^{49}$. Aşırı telefon kullanımı ile zayıf akademik başar1 ve stres arasında olumsuz bir döngü oluştuğu ifade edilmektedir ${ }^{41,50}$. Bu yüzden erken yaşta ve uzun süre akıllı telefon kullanımın gençleri olumsuz etkileyebileceği düşünülmektedir. Gençlerin hayatlarını kolaylaştıran araçları kullanırken kontrolsüz ve sınırsız kullanması, bağımlılı̆̆ın gelişmesi ve sağlık problemi oluşmasını kaçınılmaz hale getirmektedir. Bu nedenle ailelerin, teknolojik araçları kullanan çocuklarına çeşitli kısıtlamalar (güvenli adreslere girebilme vb.) ve günlük kullanım süresi gibi sınırlamalar getirmesi gerekmektedir. Bilgiye ulaşım ve doğru kullanımda bireysel öğrenmeyi destekleyen bu araçlar, doğru kullanıldıklarında yarar sağlamaktadır. Ailelerin ve sağlık çalışanlarının işbirliği içinde bu durumla mücadele etmesi sorunun çözümüne katk1 sağlayacaktır.

Günlük yaşantımızı kolaylaştıran cep telefonlarının, kullanım amacı ve kullanım sürelerine dikkat edilmediğinde ciddi fiziksel ve psikolojik etkilere sahip olduğu bilinmektedir ${ }^{30,35,51}$.

Jung ve ar. Tarafindan yapılan çalışmada cep telefonu kullanma amaçları; en yüksek $(\% 69,4)$ fotoğraf ve video çekmek olup, en düşük $(\% 45,0)$ haber ve bilgiye ulaşmak olarak tespit edilmiştir. Aynı çalışmada en çok kullanılan sosyal platform; facebook $(\% 80,2)$, Instagram $(\% 61,3)$, Google $(\% 29,7)$ ve Twitter $(\% 27,0)$ olarak bulunmuştur ${ }^{52}$. Kim (2010) yapmış olduğu çalışmada da benzer sonuçlar elde edilmiştir ${ }^{50^{\circ}}$. Yapılmış çalışmalarda akıllı telefonların genellikle eğlence amaçlı kullanıldığını, akademik başarıyı arttıran uygulamalar yerine, gelişimi olumsuz etkileyen, bilgi ve donanım kazandırma amaçları olmayan sosyal platformların kullanıldığını göstermektedir ${ }^{51,53,54}$. Bizim çalışmamızda cep telefonu kullanım amaçları kişisel $(\% 56,1)$ ve sosyal amaçlı $(\% 42,2)$ olmak üzere tespit edilmiştir. Fakat bu kişisel alan içeriğgine yönelik soru sorulmadığı için kapsamı tam olarak ifade edilememektedir.

Tsan (2017)'ın çalışmasıında kişilerarası ilişsilerinde, aile yaşantısında ve kendi kariyer yaşantısında stresli olma ile akıllı cep telefonu bağımlılığı arasında ilişkinin olduğunu göstermektedir. Öğrencilerinin akademik durumlarında yaşanılan stresle baş etmek için akıllı cep telefonlarını oyun ve çevrimiçi işlevler için kullandıklarını saptamışlardır. Günlük yaşantıda olumsuz ve gergin bir durum yaşandığında uzaklaşma aracı olarak akıllı cep telefonları kullanılmaktadır ${ }^{32}$. O’Doherty ve ark. (2007) yılındaki araştırmalarında gençlerin cep telefonunu bir iletişim aracı olarak gördükleri, eğlence, bilgi edinme ve boş zamanlarını geçirmek için televizyon, yazılı medya ve bilgisayarlardan yararlanılmayı uygun gördükleri belirlenmiş$\mathrm{tir}^{55}$. Yapılmış çalışmalarda akıllı telefonların genellikle eğlence amaçlı kullanıldığını, akademik başarıyı arttıran uygulamalar yerine gelişimlerini olumsuz etkileyen, bilgi ve donanım kazandırmayan amaçlar doğrultusunda kullanıldığını göstermektedir ${ }^{53,54}$. Akııllı cep telefonları öğrenciler tarafindan akademik bașarılarının kalitesini arttırmak için kullanılmamakta, çoğunlukla sosyal ve eğlence amaçlı kullanmaktadır. $\mathrm{Bu}$ durum çocukların sağlıklı bir akademik başarı kazanmasını ve sürdürmesini engellemektedir ${ }^{53}$. Yapmış olduğumuz araştırmada, akıllı telefonun öğrencilerin günlük yaşamdaki anlamının dağılımına bakıldığında, sağlık riskini bilmeme rağmen vazgeçilmezimdir $(\% 36,4)$, yalnızlık hissetmemi önleyendir $(\% 37,6)$, prestij kaynağıdır $(\% 28,4)$, sorunlarından kaçma kaynağıdır $(\% 22,0)$, benim bir parçamdır $(\% 22,5)$, başkasına ihtiyaç hissetmemi önler $(\% 17,7)$, sıkılmamı engeller $(\% 65,0)$ seçeneklerinin akıllı telefon ölçek puanı ile anlamlı ilişki içerisinde olduğu saptanmıştır. Öğrencilerin ailesinden uzakta olması, stres ile baş edememe, akademik kaygı, telefonun sosyal ve eğlence amaçlı kullanımı gibi nedenlerden dolayı akıllı telefon kullanım süresi uzamakta ve öğrenci ile telefon arasında duygusal bağ artmaktadır. Akıllı telefon ölçek puanı ile anlamlı ilişki içerisinde olan seçeneklerin psikolojik faktörlerden oluştuğu görülmektedir. Erdem H (2016) yaptığı çalışmada öğrencilerin nomofobik (mobil telefon yoksunluğu korkusu) olma ihtimallerinin yüksek olduğu sonucuna ulaşılmıştı́ ${ }^{38}$. Verilere göre, akıllı telefonun öğrencilerin hayatında duygusal açıdan büyük bir önemi olduğunu göstermektedir. Bununla birlikte yapmış olduğumuz araştırmada, yüzde olarak öncelikle 'bilgiye kolay ulaşmamı sağlayandır $(\% 89,7)$ ' ve 'iletişim kaynağıdır $(\% 87,0)$ ' seçenekleri gelmektedir. 'Bilgiye kolay ulaşmamı sağlayandır' seçeneğini incelediğimizde internet, arama motoru, sosyal medya öncelikli olarak düşünülmektedir. 'İletişim kaynağıdır' seçeneğinin temeline indiğimizde, sosyal medyaların büyük bölümü kapladığını düşünmekteyiz. Günümüzde telefon görüşmeleri, mesajlaşmalar bile sosyal medyalar üzerinden yapılabilmektedir. 


\section{A. Özdemir, ark.}

Akıllı telefonların günlük hayatımızda birçok faydası olduğu gibi, sağlık açısından da bazı zararları olabilmektedir. Cep telefonları ve sağlık üzerine yapılmış olan araştırmalar, akıllı telefonların yaydığı yüksek frekanslı elektromanyetik (EM) radyasyonun sağlığa etkisini konu almıştır. Akıllı telefonlardan yayılan yüksek frekanslı EM radyasyonun baş ağrısı, yorgunluk, uykusuzluk, göz sağlığının bozulması, depresyon gibi rahatsızlıklara neden olduğu düşünülmektedir ${ }^{56-58}$. Kesinlik kazanan, uzun süre telefon konuşmaları sonucu kulak bölgesindeki dokularda sıcaklık artımıyla ilgili 'ısıl etki'dir. Yüksek frekanslı EM radyasyonun, dokulara enerji geçişi yaparak 1sıyı artırdığı bilimsel kanıt olarak kabul edilmektedir. Yapı olarak aşırı ısınan dokular, bozulabilir ve işlevlerini kaybedebilirler ${ }^{56}$. Bu nedenle telefon görüşmeleri sırasında kulaklık kullanımı önerilebilir. Yüksek frekanslı EM sinyallerinin kulak, göz ve kalbi etkilediğine dair belirtiler vardır. EM enterferans etkilerinin $10 \mathrm{~cm}$ mesafeye kadar olan uzaklıklarda etkili olduğu gözlemlenmiş$\operatorname{tir}^{57}$. Yüksek frekanslı EM radyasyonun zararlı etkilerini önlemek amaçlı, akıllı telefonların kullanılmayan zamanlarda vücuttan uzak tutulması önerilebilir. Araştırmamıza katılan öğrencilerin \%79,5'i cep telefonunun taşındığı yerin önemli olduğunu, \%66,5'i kalbinden uzak yerde taşımaya dikkat ettiğini, \%47,6's1 başından olabildiğince uzak yerde taşımaya dikkat ettiğini ifade etmiştir.

Akıllı cep telefonu göz, göğüs ve üreme bölgelerinden uzakta tutulmalı, kemerde ve pantolon cebinde değil, arka cepte ya da el çantasında taşınmalıdır ${ }^{56}$. Özaşçılar'ın (2012) yaptığı Genç Bireylerin Cep Telefonu Kullanımı ve Bireysel Güvenlik' araştırmasından elde edilen bulgulara göre, kız öğrenciler cep telefonlarını öncelik olarak çantalarında ve ellerinde taşımayı tercih ettiklerini, erkek öğrenciler ise genel olarak ceplerinde taşıdıklarını belirtmiştir" 59 . 'Lise öğrencilerinin cep telefonu kullanma davranışları ve cep telefonları hakkındaki görüşleri' üzerine yapılan araştırmada ise, öğrencilerin \%89,7'si telefonlarını ceplerinde, \%10,3'ü çantalarında taşıdıklarını belirtmiştir ${ }^{60}$. Bizim araştırmamıza katılan öğrencilerin \%69,3’ü cep telefonunu çantasında taşımaya dikkat ediyor. Genel olarak kız öğrencilerin tercih ettiği cep telefonumu çantamda taşımaya dikkat ederim seçeneğinin yüzdelik hesaplaması yapılırken, erkek öğrencilerin sayısının da yüzdelik hesaplama içerisine alınması, bu seçeneğin yüzdesinin düşük olmasına neden olduğu düşünülmektedir. Öğrencilerin \%27,8'i cep telefonlarını arka ceplerinde taşımaya dikkat ettiğini belirtmiştir. Öğrencilerin \%16,0’sı cep telefonlarını uyurken kapattığını belirtmiş olup bazı araştırmalar ile paralellik göstermektedir $^{3,59}$. Cep telefonun taşınması sırasında dikkat edilen özellikler ile akıllı cep telefonu kullanım ölçek puanı arasında anlamlı fark olmadığı bulunmuştur.
T.C. Ticaret Bakanlığı 2018 israf raporu incelendiğinde, akıllı cep telefonu değiştirme süresi 3,7 yıl olarak belirlenmiştir. Akıllı cep telefonunu değiştirme nedenleri arasında öncelikli olarak telefon bozulması ve yeni çıkan cep telefonunu alma isteği yer almaktadır. Yaş olarak bakıldığında, genç yaştakilerin daha sık telefon değiştirdikleri görülmektedir ${ }^{61}$. Araştırmaya katılan öğrencilerin \%96,8'i cep telefonunu değiştirmiştir, \%80,1'i bozulduğu için değiştirmiştir, \%32,0'si yeni telefon çıktığı için değiştirirken, \%9,4’ü marka takıntısından dolayı değiştirmiştir. $\mathrm{Bu}$ veriler israf raporunu onaylar niteliktedir. Akıllı telefon kapasitelerinin, zamanla yeni geliştirilen donanımların, yazılımların, uygulamaların gerisinde kalması bireyleri üst model telefon almaya doğru yönlendirmektedir. Akıllı telefonların donanımları ve özellikleri arttıkça fiyatları da artmaktadır, bu yüzden yüksek fiyatlı akıllı telefonlar daha çok tercih edilmektedir ${ }^{26}$. Araştırmaya katılan öğrencilerin verilerine göre teknik özelliklerin yetersiz kalmasından dolayı, yeni telefonun çıkması, arkadaşlarından etkilenmek seçenekleri ile akıllı cep telefonu kullanım ölçek puanı arasında anlamlı ilişki olduğu bulunmuştur. Bu veriler Sağır ve ark.'nın ifadelerini desteklemektedir.

Sonuç olarak öğrenciler arasında akıllı telefon kullanım oranı oldukça yüksektir. Öğrencilerin akıllı telefona sahip olma yaşı 18 yaşının altında olduğu belirlenmiştir. Çalışmamızda kız öğrencilerin erkek öğrencilere oranlara telefon bağımlılığı daha yüksek çıkmış bunun nedeni ise ailelerinden uzakta olma ve kız öğrencilerin daha duygusal olması olarak belirtilmiştir. Öğrencilerin akademik kaygı ve streslerinin yanı sıra telefonlarını bir eğlence amaçlı kullanmaları akıllı telefon kullanım sürelerini arttırmakta ve bu da akademik başarıyı olumsuz olarak etkilemektedir.

Ülkemizin daha sosyal ve dinamik bir topluma dönüşmesi için öncelikli olarak gerekli devlet kurumları, vakıflar, sivil toplum örgütleri, daha sonra ebeveynler, ögretmenler, sağlık çalışanları ve bireylerin kendisi akıllı telefon ve sosyal medya bağımlılığı konusunda bilinçlenmeli ve bilgilendirmelidir.

\section{Kaynaklar}

1. Dursun ÖÖ. İletişimde Dönüşümler (Editör: H. Ferhan Odabaş1), Bilgi ve İletişim Teknolojileri Işığında Dönüşümler. Ankara: Nobel Yayınları, 2010, ss:231-255.

2. Yücelten E. Üniversite Öğrencilerinde İnternet Bağımlılığı Ve Akıllı Telefon Bağımlılığının Bağlanma Stilleri İle İlişkisinin İncelenmesi. Yüksek Lisans Tezi, İstanbul: Üsküdar Üniversitesi Sosyal Bilimleri Enstitüsü 2016: 20-50.

3. Karaaslan İA, Budak L. Research on the use of mobile phone features by university students and its impact on their communication practices in everyday life. Journal of Yasar University 2012; 26(7): 4548-4525.

4. Aktaş H, Yılmaz N. Smartphone addiction in terms of the elements of loneliness and shyness of University youth. International Journal of Social Sciences and Education Research 2017; 3(1): 85-100. 


\section{Hemşirelik Öğrencilerinin Akıllı Telefon Kullanımı}

5. Şata M. Akıllı Telefon Bağımlılı̆̆ı Ölçeği'nin (ATBÖ) Türk Lise Öğrencileri İçin Uyarlama Çalışması-The Study Of Adapting Smartphone Addiction Scale (SAS) For Turkish High School Students 2016; 7(1): 156-169.

6. Demirci K, Orhan H, Demirdas A, Akpinar A, ve ark. Akıll telefon bağımlılı̆̆ 1 ölçeği'nin türkçe formunun gençlerde geçerlilik ve güvenilirliği. Klinik Psikofarmakoloji Bülteni 2014; 24(3): 226-234.

7. Polat C, Maksudunov A. Mobil Telefon Tercihinde Etki Faktörleri-Kırgızistan'daki Üniversite Öğrencileri Üzerine Bir Çalışma. CBÜ Sosyal Bilimler Dergisi 2015; 13(2): 188-208.

8. Coogan K, Kangas S. Nuoret ja kommunikaatioakrobatia, vuotiaiden nuorten k. annykk. a- ja internetkulttuurit. Nuorisotutkimusverkosto ja Elisa communications. Elisa tutkimuskeskus. Raportti 158 2001; 16-18.

9. Kemp S. Social, Digital \& Mobile Worldwide in 2014. http://wearesocial.net/blog/2014/01/social-digital-mobileworldwide2014 adresinden 09 Mayıs 2015 tarihinde alınmıştır.

10. Campbell SW. 'Perceptions of mobile phones in college classrooms’, Communication Education 2006; 55(3): 280-94.

11. Uzgören E, Mehmet Ş, Yiğit Ü. Üniversite öğrencilerinin cep telefonu Talebinde israfa yönelik Davranışlarının analizi Dumlupınar Üniversitesi Öğrencilerine Yönelik Bir UygulamaSüleyman Demirel Üniversitesi İktisadi ve İdari Bilimler Fakültesi Dergisi 2013; 18: 29-44.

12. TÜİK (Türkiye İstatistik Kurumu). Hanehalkı Bilişim Teknolojileri Kullanım Araştırması 2017, 2015-2016. http://www.tuik.gov.tr/PreTablo.do?alt_id=1028 (Erişim tarihi 29.06.2019).

13. Poushter J. Smartphone Ownership and Internet Usage Continues to Climb in Emerging Economies 2016 http://www.pewglobal.org/2016/02/22/smartphone-ownershipand-internet-usage-conti-nues-to-climb-in-emergingeconomies/ Erişim Tarihi 03.07.2019.

14. Oliver B, Goerke V. “Australian Undergraduates' Use and Ownership of Emerging Technologies: Implications and Opportunities For Creating Engaging Learning Experiences For The Net Generation”, Australasian Journal of Educational Technology 2007; 23(2).

15. ITU 2018. International Telecommunications Union: World Telecommunications Indicators. Retrieved July 3, 2019 (http://www.itu.int/ict/statistics).

16. Erdem H, Kalkın G, Türen U, Deniz M. Üniversite Öğrencilerinde Mobil Telefon Yoksunluğu Korkusunun (Nomofobi) Akademik Başarıya Etkisi. Süleyman Demirel Üniversitesi İktisadi ve İdari Bilimler Fakültesi Dergisi 2016;21(3):923-936.

17. Doğan U, İlçin TN. Lise Öğrencilerinde Problemli Akıllı Telefon Kullanımının Sosyal Kaygı Ve Sosyal Ağların Kullanımına Aracılı Etkisi. Adıyaman Üniversitesi Sosyal Bilimler Enstitüsü Dergisi 2016; 1(1): 99.

18. Egger O, Rauterberg M. Internet behaviour and addiction. Yüksek lisans tezi, Swiss Federal Institute of Technology Üniversitesi, Zurih, Switzerland, 1996.

19. Comings DE. Tourette's syndrome: A Behavioral Spectrum Disorder. Behavioral Neurology of Movement Disorders. New York: Raven, 1995

20. Stein DJ, Hollander E, Simeon D, Cohen L, et al. Neurological soft signs in female trichotillomania patients, obsessivecompulsive disorder patients, and health control subjects. J Neuropsychiatry Clin Neurosci 1994; 6: 184-187.

21. Tossell C, Kortum P, Shepard C, Rahmati A, et al. Exploring Smartphone Addiction: Insights from Long-Term Telemetric Behavioral Measures. International Journal of Interactive Mobile Technologies (iJIM) 2015; 9(2): 37-43.

22. Telekom http://www.telekomhaber.com/haber.asp?haber_id=29874\&tur Erișim tarihi: Erișim Tarihi 01.06.2011
23. Çelik B. Cellular telephony in Turkey: A technology of selfproduced modernity. European Journal of Cultural Studies 201;14(2) : 147-161.

24. Lee H, Ahn H, Choi S, Choi W. The SAMS: smartphone addiction management system and verification. J Med Syst 2014; 38(1): 1.

25. Noyan, C. O., Enez-Darçın, A., Nurmedov, S., Yılmaz, O. ve Dilbaz, N. (2015). Akıllı Telefon Bağımlılı̆̆ Ölçeğinin Kısa Formunun üniversite öğrencilerinde Türkçe geçerlilik ve güvenilirlik çalışması. Anadolu Psikiyatri Dergisi, 16, 73-81.

26. Sağır A, Eraslan H. Akıllı Telefonların Gençlerin Gündelik Hayatlarına Etkisi: Türkiye'de Üniversite Gençliği Örneği. International Journal of Society Researches 2019; 10(17): 48-78.

27. Alavi SS, Maracy MR, Jannatifard F, Ojaghi R, et al. The psychometric properties of cellular phone dependency questionnaire in students of Isfahan: a pilot study. J Educ Health Promot 2014; 3: 71

28. Sanchez-Carbonell X, Beranuy M, Castellana M, Chamarro A, et al. La adicción Internet $\mathrm{y}$ al móvil. O Moda o trastorno? Adicciones 2008; 20: 149-60.

29. Mazaheri MA, Najarkolaei FR. Cell phone and Internet addiction among students in Isfahan University of Medical Sciences (Iran). J Health Policy Sustain Health 2014; 1: 101-5.

30. Kuyucu M. Gençlerde Akıllı Telefon Kullanımı Ve Akıllı Telefon Bağımlılığı Sorunsalı: "Akıllı Telefon (kolik)” Üniversite Gençliği Global Media Journal TR Edition 2017; 7(14): 328-359.

31. Tatlı H. Akıllı Telefon Seçiminin Belirleyicileri: Üniversite Öğrencileri Üzerine Bir Uygulama. Çankırı Karatekin University Journal of The Faculty of Economics and Administrative Sciences Y 2015; 5(2): 549-567.

32. Kuang Tsan C, Fu Yuan H. Study on Relationship Among University Students' Life Stress, Smart Mobile Phone Addiction, and Life Satisfaction. J Adult Dev 2017; 24(2): 109-118.

33. Çakır Ö, Oğuz E. The Correlation between High School Students' Loneliness Levels and Smart Phone Addiction. Mersin University Journal of the Faculty of Education 2017; 13(1): 418-429.

34. Aktas H, Yılmaz N. Smartphone addiction in terms of the elements of loneliness and shyness of University youth. International Journal of Social Sciences and Education Research 2017; 3(1): 85-100

35. Keskin T, Ergan M, Başkurt F, Başkurt Z. Üniversite Öğrencilerinde Akıllı Telefon Kullanımı Ve Baş Ağrısı İlişkisi. Adıyaman Üni Sağlık Bilimleri Derg 2018; 4(2): 864-873.

36. Martinotti G, Villella C, DiThiene D, DiNicola M, et al. Problematic mobile phone use in adolescence: a cross-sectional study. J Public Health 2011; 19(6): 545-551.

37. Sánchez-Martínez M, Otero A. Factors associated with cell phone use in adolescents in the community of Madrid. Cyberpsychol Behav 2009; 12(2): 131-137.

38. Erdem H, Kalkın G, Türen U, Deniz M. Üniversite Öğrencilerinde Mobil Telefon Yoksunluğu Korkusunun (Nomofobi) Akademik Başarıya Etkisi. Süleyman Demirel Üniversitesi İktisadi Ve İdari Bilimler Fakültesi Dergisi 2016; 21(3): 923-936.

39. Erdem H, Kalkın G, Türen U, Deniz M. Üniversite Öğrencilerinde Mobil Telefon Yoksunluğu Korkusunun (Nomofobi) Akademik Başarıya Etkisi. Süleyman Demirel Üniversitesi İktisadi Ve İdari Bilimler Fakültesi Dergisi 2016; 21(3): 923-936.

40. Şar AH. Examination of loneliness and mobil phone addiction problem observed in teenagers from the some variables. The Journal of Academic Social Science Studies International Journal of Social Science 2013; 6(2): 1207-1220.

41. Jamir L, Duggal M, Nehra R, Singh P, et al. Epidemiology of technology addiction among school students in rural India. Asian Journal of Psychiatry 2019; 40: 30-38. 


\section{A. Özdemir, ark.}

42. Lam LT, Peng ZW. Effect of pathological use of the internet on adolescent mental health. Arch Pediatnir Adolesc Med 2010; 164(10): 901-6.

43. Nikhita CS, Jadhav PR, Ajinkya SA. Prevalence of mobile phone dependence in secondary school adolescents. J Clin Diagn Res 2015; 9(11): VC06-VC09.

44. Sharma P, Bharati A, Desousa A, Shah N. Internet addiction and its association with psychopathology: a study in school children from Mumbai, India. Natl J Commun Med 2016; 7(1): 1-4.

45. Erten P. Z kuşağının dijital teknolojiye yönelik tutumları. Gümüşhane Üniversitesi Sosyal Bilimler Enstitüsü Elektronik Dergisi 2019; 10(1): 190- 202.

46. Al-Hadidi F, Bsisu I, AlRyalat SA, Al-Zu’bi B, et al. Association between mobile phone use and neck pain in University students: A cross-sectional study using numeric rating scale for evaluation of neck pain. PLoS One 2019; 14(5): e0217231.

47. Leung L. Stressful life events, motives for internet use, and social support among digital kids. Cyberpsychol Behav 2007; 10(2): 204-214.

48. Anand N, Thomas C, Jain PA, Bhat A, et al. Internet use behaviours, internet addiction and psychological distress among medical college students: a multicenter study from South India. Asian J Psychiatr 2018; 37: 71-77.

49. İHH (2015). Teknoloji Kullanımı Ve Bağımlılığı Açısından Türkiye Gençliğinin Fotoğrafi. İnsani Ve Sosyal Araştırmalar Merkezi, https://insamer.com/tr/teknoloji-kullanimi-vebagimliligi-acisindan-turkiye-gencliginin-fotografi_182.html, Erişim Tarihi: 24.05.2019

50. Kim HS, Choi YH, Yoo SJ. The study on the relations among ego-identity, stress, and internet addiction in high school students. J Korean Acad Psychiatr Ment Health Nurs 2010; 19(2): 173-185

51. Curtis BL, Ashford RD, Magnuson IK, Ryan-Pettes SR. Comparison of Smartphone Ownership, Social Media Use, and Willingness to Use Digital Interventions between Generation Z and Millennials in the Treatment of Substance Use: CrossSectional Questionnaire Study. J Med Internet Res 2019; 21(4): e13050.
52. Sang In Jung, Na Kyung Lee, Kyung Woo Kang, Kyoung Kim, et al. The effect of smartphone usage time on posture and respiratory function. J Phys Ther Sci 2016; 28(1): 186-189.

53. Van der Schuur WA, Baumgartner SE, Sumter SR, Valkenburg PM. The consequences of media multitasking for youth: a review. Computers in Human Behavior 2015; 53: 204-215.

54. Labăr AV, Tepordei AM. The interplay between time perspective, internet use and smartphone in-class multitasking: A mediation analysis. Computers in Human Behavior 2019; 93: 3339.

55. O’Doherty K, Rao S, Mackay Maio M. "Young Australians' Perceptions of Mobile Phone Content and Information Services: An Analysis of the Motivations Behind usage”. Young Consumers 2007; 8(4): 257-268.

56. Atakan Y. Cep Telefonları Ve Sağlığımız?. https://www.fmo.org.tr/wp-content/uploads/2016/01/CEPTELF-RADYASYON-YENI-ATAKAN090716.pdf (Erișim Tarihi: 29.06.2019).

57. Amca HA, İlkan M. Mobil Telefonlar Ve Baz İstasyonları Tarafından Yayılan Mikrodalga Sinyallerin İnsan Sağlığı Üzerindeki Etkileri. , Doğu Akdeniz Üniversitesi Bilgisayar Ve Teknoloji Yüksek Okulu 2016.

58. Yusufoğlu ÖŞ, Boş Zaman Faaliyeti Olarak Akıllı Telefonlar Ve Sosyal Yaşam Üzerine Etkileri: Üniversite Öğrencileri Üzerine Bir Araştırma. İnsan Ve Toplum Bilimleri Araştırmaları Dergisi 2017; 6(5):2414-2434

59. Özaşçılar M. Genç Bireylerin Cep Telefonu Kullanımı Ve Bireysel Güvenlik: Üniversite Öğrencilerinin Cep Telefonunu Bireysel Güvenlik Amaçlı Kullanımları. Sosyoloji Araştırmalar1 Dergisi/Journal Of Sociological Research 2012; 15(1).

60. Ergin A, Uzun SU, Bozkurt Aİ. Lise öğrencilerinin cep telefonu kullanma davranışları ve cep telefonları hakkındaki görüşleri. , Dicle Tıp Dergisi 2014; 41(3): 542-547

61. T.C. Ticaret Bakanlığı. 2018 israf raporu. https://www.ticaret.gov.tr/haberler/2018-İsraf-Raporu aciklandi (Erişim Tarihi 24.05.2019).

62. Çakır F, Demir N. Üniversite Öğrencilerinin Akıllı Telefon Satın Alma Tercihlerini Belirlemeye Yönelik Bir Araştırma. Dokuz Eylül Üniversitesi İktisadi ve İdari Bilimler Fakültesi Dergisi 2014; 29(1): 213-243. 